\title{
Frozen abdomen complicated with midline heterotopic peritoneal ossification: case report
}

\author{
Abdomen congelado complicado con osificación peritoneal heterotópica de la línea \\ media: reporte de un caso
}

\section{Ana P. Meléndez-Fernández ${ }^{1 *}$, Ricardo Villa-Sierra ${ }^{1}$, Ana G. Góngora-Acosta ${ }^{1}$, Eugenio J. Abreu-Rejón', Elías Hernández-Cruz', Fernando E. De la Torre y Rendón², Alejandro U. Tapia-Yáñez², and}

Raúl E. Albarrán-Castillo ${ }^{1}$

'Department of Surgery; ${ }^{2}$ Department of Pathology, Adolfo Lopez Mateos Regional Hospital, Instituto de Seguridad y Servicios Sociales de los Trabajadores del Estado (ISSSTE), México City, Mexico

\begin{abstract}
Background: Heterotopic ossification consists in abnormal differentiation of mesenchymal cells into osteoblastic cells, which may occur in the abdominal cavity. Case report: A 54-year-old male who presents with small bowel obstruction, performing a laparotomy, adhesiolysis, and managed with an open abdomen with Bogota bag; the abdominal wall was closed on the $5^{\text {th }}$ post-operative day. Due to recurrent symptoms of intestinal obstruction, he required a re-laparotomy after 14 days, finding a frozen abdomen with midline calcified peritoneum. Conclusion: This entity is a rare benign form of ossification, associated with an inflammatory environment due to trauma after multiple abdominal interventions.
\end{abstract}

Key words: Frozen abdomen. Heterotopic ossification. Peritoneum ossification. Small bowel obstruction.

\section{Resumen}

Antecedentes: La osificación heterotópica consiste en la diferenciación anómala de las células mesenquimatosas en osteoblásticas que puede ocurrir en la cavidad abdominal. Caso clínico: Varón de 54 años con obstrucción intestinal que amerita tratamiento quirúrgico con laparotomía, adherenciólisis y manejo con bolsa de Bogotá para abdomen abierto. Se realizó el cierre de la pared abdominal en el quinto día posquirúrgico. Presentó recurrencia de la oclusión intestinal y se realizó una nueva laparotomía tras 14 días, encontrando un abdomen congelado con calcificación peritoneal. Conclusión: Esta es una forma rara y benigna de osificación asociada a un ambiente proinflamatorio debido al traumatismo tras múltiples intervenciones quirúrgicas.

Palabras clave: Abdomen congelado. Osificación heterotópica. Osificación peritoneal. Oclusión de intestino delgado.

\section{Introduction}

Heterotopic ossification $(\mathrm{HO})$ is an extremely rare benign condition, which consists in abnormal differentiation of mesenchymal cells into osteoblastic cells. It may affect musculoskeletal system, skin, fascia, abdominal midline, and intraabdominal structures ${ }^{1}$. The exact causes for the development of this pathology are

\footnotetext{
Correspondence:

*Ana P. Meléndez-Fernández

Avda. Universidad, 1321

Date of reception: 07-03-2019

Cir Cir. 2021:89(1):97-100

C. P. 01030 , México City, Mexico

Date of acceptance: 13-09-2020

ontents available at PubMed

E-mail: ana.paulina.mf@gmail.com

DOI: 10.24875/CIRU.19001156

www.cirugiaycirujanos.com

0009-7411/@ 2020 Academia Mexicana de Cirugía. Published by Permanyer. This is an open access article under the terms of the CC BY-NC-ND license (http://creativecommons.org/licenses/by-nc-nd/4.0/).
} 
not well known; however, several cases have been associated with previous musculoskeletal and abdominal trauma (including surgical procedures), gastric carcinoid tumor, appendiceal mucocele, and colonic polyps ${ }^{1}$. Intraabdominal $\mathrm{HO}$ may involve mesentery, abdominal wall or peritoneum, been the last one the least frequent ${ }^{2}$. Patients generally present with clinical manifestations of intestinal obstruction, but in our case, the patient also developed frozen abdomen, which consists in adhesions between the abdominal viscera and the undersurface of the anterior abdominal wall ${ }^{3}$. We report a case of small bowel obstruction complicated with midline heterotopic peritoneal ossification, which occurred after the fourth laparotomy associated with previous adhesions.

\section{Case report}

A 54-year-old Mexican man presented to the emergency department in our institution with small bowel obstruction secondary to adhesions, with prior history of laparotomy due to acute complicated appendicitis with peritonitis 19 years ago, with a second intervention due to small bowel obstruction secondary to adhesions after $24 \mathrm{~h}$ of the first operation.

In this occasion, after $48 \mathrm{~h}$ of conservative management and without showing any clinical improvement, he went through laparotomy with adhesiolysis of multiple firm adhesions, mainly in the terminal ileum; he was left with an open abdomen, which was closed on the $5^{\text {th }}$ post-operative day. His post-operative evolution was torpid, presenting the next 14 days with intolerance to solid diet, abdominal distention, and intermittent liquid evacuations. An abdominal computed tomography (CT) with double contrast was conducted, identifying mechanical small bowel obstruction due to probable new adhesions figure 1.

A second laparotomy was performed, finding a frozen abdomen with the parietal peritoneum abnormally firm, thickened, petrified at the intraabdominal midline, which made it impossible to liberate, having as an only choice to perform a jejunostomy at the level of the abdominal wall incision figure 2 .

A biopsy of the parietal peritoneum was sent to histopathology reporting extensive metaplastic bone deposition with osteoblastic activity without atypia or evidence of malignancy.

The patient developed short bowel syndrome requiring permanent parenteral nutrition and correction of electrolytic disturbances and acute renal failure. After 2 months, he was discharged. During his follow-up, he has remained stable, with mild malnutrition and without

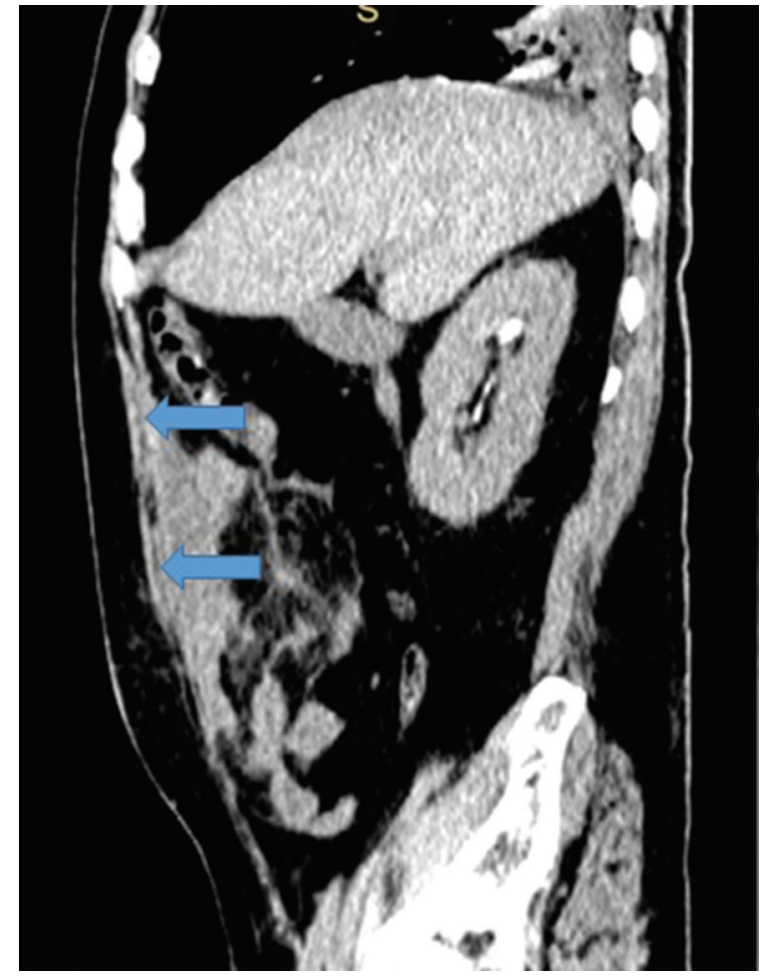

Figure 1. Abdominal computed tomography scan showing peritoneum calcification at the midline incision (arrow).

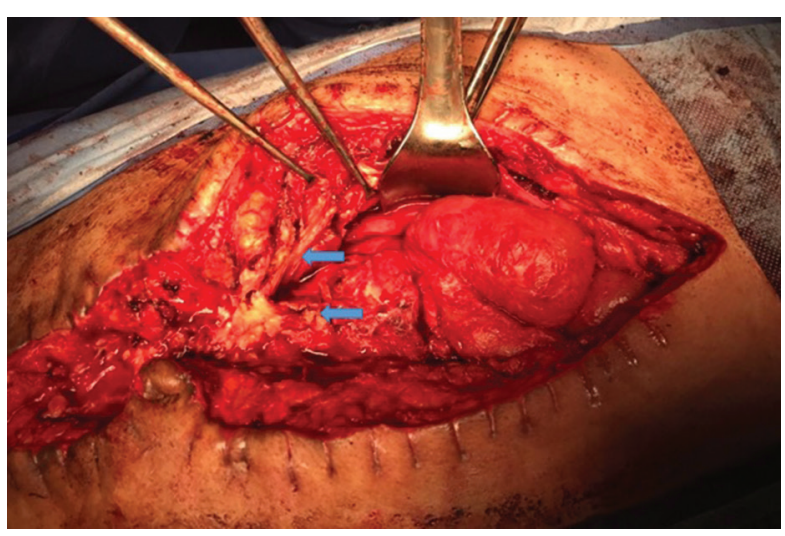

Figure 2. Laparotomy showing calcified tissue (arrow) with frozen abdomen

electrolytic disturbances, being strictly followed in consult by multiple specialties figure $3 \mathrm{~A}$ and $\mathrm{B}$.

\section{Discussion}

Primary $\mathrm{HO}$ is a rare condition where bone develops in a tissue, which does not normally undergo ossification ${ }^{4}$.

Also known as intraabdominal myositis ossificans, it consists on deposition of organized calcium-containing 

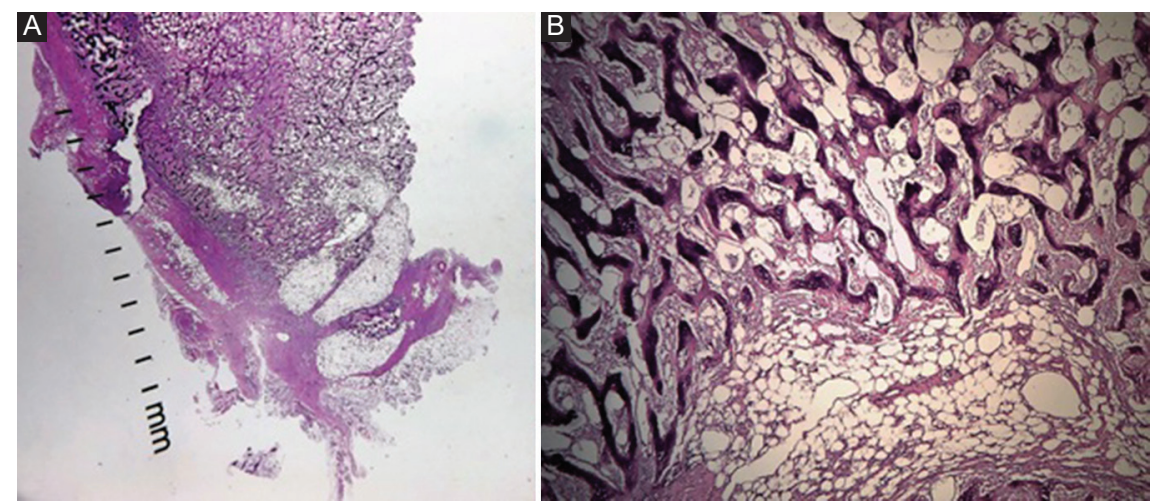

Figure 3. A-B: in both images, extensive immature trabecular bone with an osteoblastic rim is surrounded with adipose tissue. The panoramic view (x1) shows peripheral reparative fibrosis. The inflammatory component was irrelevant. There was not atypia or neoplastic elements (hematoxylin and eosin, $x 1$ and $\times 40$ ).

osteoblasts and structured bone layers. There are three types of HO: myositis ossificans circumscripta, myositis ossificans progressiva, and traumatic myositis ossificans being the last one present in our patient ${ }^{5}$. This pathology is a rare and benign form of ossification related to previous abdominal trauma and/or abdominal surgery. The physiopathology of $\mathrm{HO}$ is not clear yet; however, it can be explained by two theories: (1) implant of osteogenic cells from perichondrium, periosteum of pubic symphysis or sternum, who have migrated during laparotomy or trauma and (2) process of osteoblastic metaplasia of pluripotent mesenchymal cells in response to severe inflammatory environment due to trauma or repetitive surgical manipulation of the tissue. Bone formation generally occurs within weeks or days after the surgery ${ }^{6-8}$.

This entity has a male prevalence within the age of 22-80 years old. In most of the reported cases, abdominal trauma or previous surgery is the trigger event, clinically behaving as small bowel obstruction with oral intolerance, distension, and abdominal pain $^{2,9}$.

CT scan imaging provides evidence of peritoneal ossification guided by the value of Hounsfield units; however, in this specific case, the osteogenic tissue was not demonstrated. Diagnosis is generally made as a transoperative finding 9 .

It has a good prognosis without evidence of malignancy and if the patient's general condition allows it, we should aim for conservative management; nevertheless, in the presence of asymptomatic patient or clinical deterioration, surgical intervention is required ${ }^{9}$.

In this case, having a history of multiple surgeries causing intestinal obstruction secondary to adhesions, not resolving with medical management, we decided surgical intervention, performing an exploratory laparotomy ${ }^{9}$. The findings were extensive intestinal adhesions; hence, we made an adhesiolysis which predisposed a new acute inflammatory process. In addition, he was left with a temporarily open abdomen handled with Bogota bag to monitor the possibility of intestinal perforation, exposing the viscera and leading to fluid and heat loss ${ }^{10}$. Regardless of the method used, the ongoing loss of peritoneal fluid is associated with a net loss of protein. Since the total daily volume of fluid removed can be over $1 \mathrm{I}$, the net loss of protein per day can lead to protein-calorie malnutrition, resulting in delayed healing, constant inflammatory stimuli, and therefore deficient tissues ${ }^{10}$.

In our case, abdominal wall ossification occurred due to repetitive surgical injuries, as reported in the literature, with constant inflammatory stimulus until bone formation ${ }^{5}$. Open abdomen has not been described as a risk factor for $\mathrm{HO}$; however, in this specific case, we considered that this entity and therefore the abdominal inflammatory wall response, probably contributed to the process of abdominal wall ossification.

\section{Conflicts of interest}

No conflicts of interest to declare.

\section{Ethical disclosures}

Protection of human and animal subjects. The authors declare that no experiments were performed on humans or animals for this study. 
Confidentiality of data. The authors declare that they have followed the protocols of their work center on the publication of patient data.

Right to privacy and informed consent. The authors have obtained the written informed consent of the patients or subjects mentioned in the article. The corresponding author is in possession of this document.

\section{References}

1. Arvind M, Sathiamurthy N, Singh-Nijhar J. Mesenteric bones: intra-abdominal heterotopic ossification. Med J Malaysia. 2018;73:110-1.

2. Ioannidis O, Sekouli A, Paraskevas G, Kotronis A, Chatzopoulos S Papadimitriou N. Intra-abdominal heterotopic ossification of the peritoneum following traumatic splenic rupture. J Res Med Sci. 2012;17:92-5.
3. Lombardo G, Latifi R, Leppaniemi A. Practical approach to patient with a hostile abdomen: clinical scenarios. In: Latifi R, editors. Surgery of Complex Abdominal Wall Defects. Cham: Springer; 2017

4. Ferreia C, Gomes C, Melo A, Tenreiro N, Pinto B, Moreira H, et al. Heterotopic mesenteric and abdominal wall ossification two case reports in one institution. Int J Surg Case Rep 2017;37:22-5.

5. Hogan N, Caffrey E, Curran S, Sheehan M, Joyce M. Heterotopic ossification of the abdominal wall. Int J Surg Case Rep 2012;3:489-91.

6. Ioannidis O, Sekouli A, Paraskevas G, Kotronis A, Chatzopoulos S, Papadimitriou $\mathrm{N}$, et al. Intra-abdominal myositis ossificans in an asymptomatic patient during closure of a Hartmann's colostomy. J Surg Case Rep 2016;11:1-3.

7. Di Paolo N, Sacchi G, Lorenzoni P, Sansoni E, Gaggiotti E. Ossification of the peritoneal membrane. Perit Dial Int. 2004;24:471-7.

8. Merrell J, Sadro C, Chew F. Heterotopic mesenteric ossification after blunt abdominal trauma and multiple surgical operations. Radiol Case Rep. 2008;3:243.

9. Roriz D, Abreu I, Costa J, Belo-Soares P, Caseiro-Alves F. An unusual case of extensive peritoneal calcification: a case report. Eur J Radiol Open 2015;2:7-10.

10. Patel NY, Cogbill TH, Kallies KJ, Mathiason MA. Temporary abdominal closure: long-term outcomes. J Trauma. 2011;70:769-74 